\title{
"Economically inefficient and legally untenable": constitutional limitations on the introduction of central bank digital currencies in the EU
}

\author{
Jay Cullen ${ }^{1,2}$ (D)
}

Accepted: 2 June 2021 / Published online: 22 June 2021

(c) The Author(s), under exclusive licence to Springer Nature Limited 2021

\begin{abstract}
ECB officials have recently poured scorn on the notion that the ECB could introduce a central bank digital currency (CBDC) in the Eurozone, with one labelling such an initiative as "economically inefficient and legally untenable." This article assesses the justifications for these claims from legal and economic perspectives. It finds that, based upon prevailing ECB policies and the myriad options available for CBDC design, such claims are flawed. The article further explains that the ECB's reticence to consider the introduction of CBDC may impair the development of payments systems and obstruct financial inclusion.
\end{abstract}

Keywords CBDC $\cdot$ Central bank digital currency $\cdot$ EU $\cdot$ Constitution $\cdot$ Market neutrality $\cdot$ Financial stability

\section{Introduction}

An acute challenge facing modern financial regulation is to ensure that the considerable benefits of the financial system are dispersed fairly amongst citizens and businesses. The emergence of new financial technologies such as cryptocurrencies and alternative currency systems holds promise for widening access to finance and addressing wider socioeconomic challenges, but they also present considerable challenges in their own right including issues of consumer protection, and the dangers of data mismanagement, preservation of privacy and the mitigation of cybersecurity risks. Cryptocurrencies such as Bitcoin, for example, are prone to security issues and susceptible to theft [73]. They are also often subject to intense financial speculation and therefore extremely volatile, making them deficient stores of value and difficult to scale [25]. Alternative currency systems, including so-called stablecoins such as Facebook's Diem [63], ${ }^{1}$ likely offer more stability than cryptocurrencies, but if widely adopted, they also threaten to concentrate power further in the hands of large multinational corporations which are subject to little democratic oversight [66]. Moreover,

\footnotetext{
$\triangle$ Jay Cullen

jay.cullen@york.ac.uk

1 University of York, York, UK

2 Faculty of Law, University of Oslo, Oslo, Norway
}

the financial stability dangers of privately created "monies", designed to operate like regulated money but in largely unregulated spaces, are well documented [67].

Given these trends, a much-heralded recent development in Fintech has been the mooted introduction of central bank digital currencies (CBDCs). In structural terms, CBDCs would, like paper bank notes and coins, be fiat money: a liability of the central bank, serving as legal tender and held as either balances in accounts at the central bank or in the form of tokens in wallets constituting claims on digital central bank money [5, pp. 85-100]. The technology to operate such services is already in existence, but there remains huge resistance in many jurisdictions to implementing what would be a revolutionary development in financial system operation. There are fears that central banks might distort competition by supplanting commercial banks as the primary transmitter of retail and business payments. The creation of a CBDC might lead to pressure being placed upon central banks to engage in credit issuance, which would concentrate even greater power in their hands and raise fundamental questions concerning central bank independence. If households and businesses convert their bank deposits on a wholesale basis into CBDCs, banks could lose almost all of their stable funding, causing a collapse in bank liquidity. During a systemic crisis, a run to CBDCs by bank depositors might destroy the banking system.

\footnotetext{
${ }^{1}$ Diem is the latest name of the currency proposed by the Libra Association in its White Paper v2.0 [58].
} 
In the European context, the European Central Bank (ECB) has thus far been reticent to countenance the introduction of a CBDC, partly on the basis of the claims made above. Recently, the ECB suggested that as a legal matter, the ECB could introduce a CBDC for households and other units which are currently not central bank counterparties under Article 127(2) TFEU as a clearing and settlement instrument or under Article 128 of the TFEU as a financial instrument equivalent to a banknote. ${ }^{2}$ However, it has also been asserted by ECB officials that EU authorities may be constitutionally barred from promoting such an instrument. This view was summarised recently in a speech by an executive member of the ECB Board, who claimed that the introduction of a CBDC would, thanks to its effects on the banking sector, be "economically inefficient and legally untenable [62]". The ECB's logic in not supporting CBDC is that by introducing access to electronic central bank money for retail consumers and businesses the central bank might disintermediate banks and thus impact financial stability. Arguably, such a development would also undermine its much-vaunted position of "market-neutrality"; as the same ECB official notes, the "EU Treaty provides for the ECB to operate in an open market economy, essentially reflecting a policy choice in favour of decentralised market decisions on the optimal allocation of resources [62, 64]." The ECB's approach to payments technology development is therefore subsumed as part of its broader market neutrality policy position, which has as its aim minimisation of the central bank's footprint in markets in order to avoid potential distortions and misallocation of resources [35]. Indeed, the German central bank has claimed that market neutrality is "anchored in Article 127 of the EU Treaty [72]".

The purpose of this article is not to advocate normatively for the introduction of a CBDC. Rather, the article's primary aim is to address the ECB's claims and position them within the broader literature on retail payments systems, financial stability and multi-level financial governance, questions which are fundamental to the relationship between the state, money and law [16]. The ECB's capacity to introduce a CBDC instrument in this context has not

\footnotetext{
${ }^{2}$ Article 127(2) TFEU [23] would operate in conjunction with Article 17 of the ESCB Statute, which states: "In order to conduct their operations, the ECB and the national central banks may open accounts for credit institutions, public entities and other market participants and accept assets, including book entry securities, as collateral"; or Article 22 of the ESCB statute [24], which states: "The $\mathrm{ECB}$ and national central banks may provide facilities, and the ECB may make regulations, to ensure efficient and sound clearing and payment systems within the Union and with other countries." Article 128 TFEU would operate in conjunction with the first sentence of Article 16 of the Statute of the ESCB, which states: “...[T]he Governing Council shall have the exclusive right to authorise the issue of euro banknotes within the Union".
}

been addressed directly in the literature, nor have the links between its neutrality creed and its pronouncements on digital money. As the article will argue, the purported incompatibility between the ECB's mandate and the upgrading of payments infrastructure via a CBDC is less convincing than it may appear, principally for two reasons. Firstly, relying on the ECB's market neutrality creed is arguably not sustainable, given that the ECB frequently engages in marketdistorting activities in pursuit of higher-level priorities in several domains including in monetary policy operations and bank supervisory practices [37]. Importantly, relying on a neutrality stance with regard to CBDCs ignores the advantages that incumbent financial institutions presently enjoy over rivals with regard to existing payments infrastructures. These advantages are a function of past decisions by central banks on how best to manage the payments system-they are endemic, institutional and systematised - and cannot be corrected by competitive market pressures. Concomitantly, insistence upon adopting a neutral stance also discounts the very real benefits that a CBDC may bring, in particular, the acceleration of financial inclusion efforts with regard to unbanked and underbanked EU citizens. ${ }^{3}$

Secondly, the financial stability dimensions of the introduction of a CBDC may not be as perilous for the retail banking system as many suggest, especially where the envisaged augmented CBDC payments system is designed to stand alongside existing commercial bank deposit-taking. There are design options available to central banks which would diminish the impact that such payment instruments would exert on whilst allowing citizens more choice and flexibility in their selection of financial services. If such designs were adopted, a CBDC, rather than threatening the financial system, might be financial stability enhancing, by weakening the hold that large financial institutions currently enjoy over payments infrastructure in the EU [31].

These issues highlight the complexities of multi-level regulatory enforcement and control. The analysis also sheds light on the significant tensions at play in the context of the ECB's wider constitutional role and its interplay with other administrative instrumentalities. The EU Commission, for example, has recently launched a digital finance strategy, the central aim of which is to provide a "competitive EU financial sector that gives consumers access to innovative

\footnotetext{
${ }^{3}$ According to recent research by the World Savings Bank Institute, more than 37 million adult EU citizens (8.6\% of Europe's adult population) lack access to formal financial services. The numbers in Eastern Europe (including Euro area countries) are noteworthy: in Romania, almost $40 \%$ of the population is unbanked; in Bulgaria, it is $37 \%$. Hungary (27.7\%), Slovakia (22.8\%), and Lithuania and Poland (both $22.1 \%$ ) follow. Even countries with relatively advanced financial systems have a large proportion of unbanked adults, including Italy (12.7\%), Portugal (12.6\%) and Greece (12.5\%) [74]
} 
financial products, while ensuring consumer protection and financial stability [41]". A ubiquitous CBDC could be part of such a strategy, especially given the EU's payment systems continued fragmentation, which continues to undermine the EU's goal of a fully functional internal capital market. It would mitigate potential divergence between national central banks within the ESCB in this field; Sweden, for example, has indicated its intention to introduce CBDCs at the national level, with other non-Euro area EEA countries actively exploring the possibility. ${ }^{4}$ Introducing a CBDC at the European level arguably would also assist the ECB in preserving control over the EU's monetary system in the face of both global and wider monetary market competition and support the international role of the euro, which remains a central aim of EU leaders [37, p. 14]. In light of the increasing likelihood of some nation-states adding CBDCs to their financial market infrastructures, it is a useful exercise to survey questions of EU jurisdiction and competence as bases for objection to the introduction of such tools. $^{5}$

The next section of the article provides a brief primer on the existing payments system, followed by a brief description of CBDC and objections to its introduction in the EU. The third section assesses these claims against evidence that the ECB directly intervenes in financial regulation to favour particular market participants or products, as well as the finding that introducing a CBDC might be financial stability enhancing. The final section concludes.

\section{Existing payments systems: function, operation and flaws}

At root, a payments system is the system through which units in an economy-governments, households and businesses-move money between one another. There are two dominant payment media in modern economies: electronic money (often bank deposits) and physical currency. Electronic payments systems are used in lieu of tendering physical currency in transactions and comprise by far the largest payment instrument by volume in the EU, although from a

\footnotetext{
${ }^{4}$ In October 2020, the governor of the Swedish central bank stated: "There shall be digital state money as legal tender, an e-krona, issued by the Riksbank [54]". The Icelandic central bank has stated that: "The time is right to open discussions of this topic and to assess the need to digitise cash by issuing a rafkróna in Iceland [19]”. Norway's central bank is in its third phase of assessment of CBDC [65].

5 The world's first digital currency was introduced in the Bahamas in 2020. The "Sand Dollar" has been introduced to "advance more inclusive access to regulated payments and other financial services for under-serviced communities and socio-economic groups as well as to reduce service delivery costs and increase transactional efficiency for financial services across the Bahamas [20]”.
}

retail perspective cash use continues to predominate [38]. Cash substitutes including debit cards, credit cards, direct debits, and e-commerce payment service providers are also used to augment existing retail payment channels. The volume of cashless payments is expanding rapidly within the EU with year-on-year growth of over 8 percent [7].

At present, the vast bulk of retail payments made by cash substitute are executed via the commercial banking system. Only a limited number of commercial ("settlement" or "clearing") banks hold accounts at their national central bank (so-called reserve accounts) and engage in direct participation with the central bank's payment infrastructure. When payments are made between accounts at these banks, the central bank moves reserves (central bank money) between the reserve accounts corresponding to the amounts paid. Only the outstanding bilateral "netted" balance is transferred in reserves each day. In turn, other financial institutions which are not part of the clearing system-socalled indirect participants-hold accounts at commercial banks. When a payment is made between these financial institutions, instructions are sent to debit or credit the correspondent accounts at the clearing banks, and reserves will be transferred at the central bank level to settle the payment. This means that at present a payment made through a payments service provider that does not have a reserve account at the central bank is still transacted via reserve accounts held at the central bank by the clearing banks [8], for a technical summary]. Access to the central bank's balance sheet for a narrow set of financial institutions, referred to as a "tiered participation arrangement" (TPA), is therefore a feature of today's payments market infrastructure. These TPAs allow many participants to access the central payments system, but they must do so indirectly, building upon the settlement and clearing services provided by those institutions with access to the central bank's settlement systems. The scale of these operations as a proportion of the monetary base is striking; commercial bank money comprises the vast bulk of the Euro area money supply and is used for almost all business-to-business payment transactions [61].

In the EU in 2020, there were almost five thousand payment institutions. ${ }^{6}$ Of this number, there were approximately one thousand direct participants with settlement accounts at the Eurosystem level and almost six hundred indirect participants [39]. ${ }^{7}$ This means that approximately two-thirds of registered Euro area payment institutions have no accessdirect or indirect—-to central bank money. Network effects,

\footnotetext{
${ }^{6}$ There were 4880 payment institutions registered at the ECB on 11 May 2020. See https://www.ecb.europa.eu/stats/financial_corporatio ns/list_of_financial_institutions/html/index.en.html.

7 The European payment settlement system for euro-denominated transactions is the Trans-European Automated Real-time Gross settlement Express Transfer system (TARGET2).
} 
in combination with economies of scale and regulatory access restrictions, mean that establishing competing networks is economically unviable. Instead, the only option for rival suppliers wishing to compete in the market is to gain access to an existing installed infrastructure base. In recognition of these obstacles, the EU has attempted to expand payments market access, in the form of the second Payments Services Directive (PSD2) [43]. PSD2 enables retail and business bank customers to use third-party providers (TPPs) to manage their finances and initiate electronic payments on their behalf, removing the need for banks to actively participate in a payments service. To achieve this, PSD2 requires firms who hold individuals' payment accounts to provide TPPs with access to bank's customer data and payment functionality of users' online payment accounts. ${ }^{8}$

In spite of these reforms, there is evidence that regulatory attempts to create a competitive market-led payments market in Europe have faltered. ${ }^{9}$ Interoperability in particular remains problematic; ten EU countries still retain national card schemes that do not accept card payments from institutions in other EU Member States [33]. Attempts to introduce intra-EU card payment schemes to rival Visa and Mastercard failed in $2012,{ }^{10}$ whilst recent EU-level legislation has been cited as a major retardant of payments market liberalisation [45]. ${ }^{11}$ On this basis, a review of the bank card payments market in Europe- under the umbrella of a "European Payments Initiative" (EPI) - was recently announced. Yet, the EPI is dominated by the largest EU banks which already enjoy significant market power in EU payment markets [34]. Apart from these players, there are virtually no digital payments systems available to settle transactions in Europe. The e-money market is also increasingly fragmented, with many mobile money providers offering their services only within national borders [42]. Consumers at present in the EU are reliant upon the rails of a few large providers of settlement systems; whilst the provisions of PSD2 mandate that payments providers must be granted access to the data held by settlement banks, the network effects of holding consumer

\footnotetext{
8 Article 66(4)(c) of the Directive states that a licensed payment service provider shall "treat payment orders transmitted through the services of a payment initiation service provider without any discrimination other than for objective reasons, in particular in terms of timing, priority or charges vis-à-vis payment orders transmitted directly by the payer.".

9 As noted by the ECB President: "[W]e know that the private sector...has made [little] progress on delivering a pan-European solution for retail payments [56]".

10 The Monnet Project, a group of 24 banks drawn from across major countries in Europe tried to start a competing pan-European card system, but it was unsuccessful, partly thanks to intransigence from the EU Commission.

11 The draft legislation, which was eventually enacted, is critiqued by David Evans [47].
}

bank information mean that banks operate at a competitive advantage in relation to these payment providers. Because banks may offer bundled products alongside payment services, they can cross-subsidise their payments services and infrastructure costs and there are well-established findings that banks and other financial institutions with direct access to central bank settlement systems enjoy competitive rents from these privileges [48].

\section{CBDCs: features}

The Bank for International Settlements (BIS) has contended that CBDCs are "envisioned by most to be a new form of central bank money, that is, a central bank liability, denominated in an existing unit of account, which serve both as a medium of exchange and a store of value [9, p. 3]". A functional CBDC would provide an inclusive and stable digital counterpart to physical cash. In order to fulfil this, a CBDC should share the features of cash which make it attractive as a payment medium. Such features include trust in the issuing entity, guaranteed real-time finality and settlement, widespread acceptance, ease of use, unfettered access to the medium and legal tender status [10]. A CBDC with universal coverage would ensure access for all citizens to a simple and trustworthy method of payment and store of value, particularly in circumstances where alternative payments providers have been unable to offer transaction accounts to target populations [11]. Other considerations for the design of a CBDC include high security protections, privacy safeguards and resistance to counterfeiting.

The implications of the introduction of a retail CBDC might be seismic. Because users would be granted direct access to central bank money, the liquidity and credit risks which retail money holders are normally exposed to via bank deposits and other forms of "privately" issued money would be reduced substantially; only a central bank can credibly commit to exchanging its currency in digital form with other forms of state money at par. A CBDC would be highly beneficial for low-income households, which tend to rely heavily on cash and whose access to bank accounts may be limited. Small businesses, who are often charged large account and transaction fees, and must contend with additional charges for accepting debit and credit card payments would also benefit from the introduction of a CBDC; research suggests that removal of existing payment transaction fees has the capacity to raise GDP by as much as 3\% [12]. In the event of recession or other form of economic crisis, CBDC would facilitate more efficient provision of fiscal stimulus to citizens, thereby avoiding some of the blockages which undermine rescue and recovery efforts during downturns. CBDCs might also mitigate risks associated with TPAs, which create dependencies between payments market infrastructures, as 
well as credit, liquidity and operational risks for financial institutions and the payments system at the aggregate level [39].

\section{CBDC: objections}

As noted above, there are a number of objections to the introduction of CBDC. In the context of the EU, it is claimed that because the ECB must remain "neutral" in its dealings with both the market and the technology underpinning financial instruments, introducing a CBDC might breach this principle [62]. Market and technology neutrality in relation to the role of the central bank denote the notion that certain asset markets and/or regulatory prescriptions vis-à-vis technology introduced in institutional or regulatory frameworks should not place some market participants at a disadvantage in comparison with others. In the context of CBDCs, claims are made frequently, for example, that central banks' cost efficiencies and potential dominance in such markets-and the fact that they are rule-setters for market participants-might stifle competition and dissuade potential alternative payment infrastructure development [27]. Because the central bank balance sheet would be available to non-bank competitors, commercial banks would be forced to compete with new entrants to the payments markets, potentially resulting in the erosion of payment-related earnings at retail banks' major profit centres. This might push commercial banks into riskier lending, a classic regulatory externality [51]. It may also stifle lending, raising the prospect that central banks themselves might be pressured to enter credit markets.

Any issuance of a CBDC instrument may also have profound implications for maintaining financial stability, a cardinal function of all modern central banks, including the ECB. The disruption to bank business models might be damaging via two distinct channels. Primarily, it is claimed that a CBDC might have a large impact on financial intermediation patterns. If retail bank deposits were made exchangeable at par for central bank money, and non-banks and individuals were permitted to hold central bank accounts, a significant proportion of bank deposits may flow into a CBDC. This would lead to the-potentially fatal-loss of low-cost and stable funding for the commercial banking system. ${ }^{12}$ Banks could attempt to address any deposit outflows by raising deposit rates or seeking other funding sources such as wholesale or bond financing, but such funding sources are more expensive and, in the case of wholesale funding, much

\footnotetext{
12 As Mersch notes: "If households were able to convert commercial bank deposits into a CBDC at a rate of 1 to 1 , they may find it far more attractive to hold a risk-free CBDC rather than bank deposits [62]".
}

less stable. Such funding structures would also be penalised by new liquidity regulations under the Basel Accords, placing cost pressures on bank balance sheets and forcing them to shrink at a time when low interest rates are impacting profitability [13].

Further, as CBDC is a fundamentally risk-free asset, there will be incentives for bank depositors to "run" from bank deposits into CBDC during periods of banking system stress. Private monetary liabilities, including bank deposits, are subject to run-risk in the presence of mistrust in the banking system. At present, during systemic financial distress depositors may shift their deposits to alternative financial institutions, into financial assets such as government securities, or withdraw their deposits in cash. The widespread availability of a safe central bank asset would give them the option to instead move their deposits into central bank money and give rise to the potential of a "digital run" even on the strongest financial institutions, leading to contagion and wider financial system instability [9]. This was witnessed during the great financial crisis (GFC), as governments in many states were forced to guarantee the entire bank deposit base in order to forestall a widespread run on national banking systems [17].

The remainder of the article addresses these claims.

\section{Market neutrality}

The claim that EU institutions-particularly the ECBremain market-neutral is difficult to sustain when considered in certain contexts. Take, for example, the ECB's approach to monetary policy, its primary constitutional function. For many years, price stability has been targeted by central banks, with the aim of keeping price inflation in a longrun corridor of around 2\% per year [32]. Particularly since the GFC, central banks have pursued many programmes to achieve this aim, including ultra-loose monetary policies such as quantitative easing (QE), and generous liquidity provision to the banking system. The scale of some of these programmes is immense; in Europe, for example, the ECB has since 2015 engaged in over four trillion euros worth of $\mathrm{QE}$, in particular through its public sector purchase programme (PSPP). ${ }^{13}$

Although the principle of market-neutrality is not enshrined in any constitutional legal framework, the ECB goes to great lengths to assure market participants that such interventions are market neutral and that it strives to

\footnotetext{
13 The launch of $€ 2.8$ trillion QE followed the failure to properly resolve the European sovereign debt crisis of 2010-2013. In response to the Covid-19 pandemic, the ECB has committed to additional QE at least $€ 1.35$ trillion [36].
} 
minimise the effect of its monetary operations on relative asset prices or the allocation of credit [21]. These rules are applied in order to reflect the ESCB's constitution as a supranational independent institution, composed of the ECB and EU state national central banks, including those outside of the euro area, requiring multi-level regulatory cooperation. Accordingly, in conducting asset purchases the ECB operates under strict principles of proportionality. Until the recent Covid-19 pandemic, this meant that purchase volumes of government bonds under the PSPP were divided between the euro area countries in two ways: (1) no more than 33 per cent of a particular issue of sovereign bonds or more than 33 per cent of the total outstanding volume of any individual sovereign could be purchased by the central bank and (2) purchases by the ECB had to be made in proportion to each national central bank's share in the ECB's capital key [4]. Similarly, in its corporate sector purchase programme (CSPP) under QE, the ECB aims to buy bonds in strict proportion to outstanding aggregate corporate bond volumes, reflecting risk premia set by financial markets.

Notwithstanding the adoption of these protocols, at a conceptual level, buying bonds issued by national treasuries is itself not "neutral" in the sense that central bank intervention in markets to place a floor under the price of a financial instrument always involves a distortion of prices. For example, it may be plausibly argued that the sovereign bond purchases in the Eurozone following the sovereign debt crisis of 2010 would breach most interpretations of the market neutrality principle. In short, during this period, many Eurozone country treasuries were experiencing great difficulty in funding their public expenditures. In many countries in the Eurozone-most notably Greece, Portugal and Ireland-the need to recapitalise the banking system following the GFC resulted in a deterioration of public finances which weighed extremely heavily on the market pricing of government bonds of those countries [57]. This in turn exerted a negative impact on the balance sheets of commercial banks which held those sovereign bonds as assets, resulting in a so-called sovereign-bank doom loop [3]. This led not only to upward pressure on government financing costs, but also downward pressure on banks' financial strength, increasing their borrowing costs in tandem, as market confidence was eroded.

The ECB responded to these pressures by offering to buy certain sovereign bonds from the relevant governments, bypassing the market, to which many of the countries concerned were beginning to lose access. Accordingly, a $€ 440$ billion temporary crisis facility for Eurozone countries-the European Financial Stability Fund (EFSF) (later replaced by the European Stability Mechanism)—was established with the express purpose of issuing bonds and other debt securities on the market to raise funds required to provide loans to Eurozone countries in need of financial support, to recapitalise banks, or buy sovereign bonds. The bonds issued were guaranteed by the remaining Eurozone members in proportion to their paid-up capital in the ECB. The response was justified by the ECB on the basis that the operations concerned were no more than a monetary policy response (via "open-market operations") to ensure liquidity in certain bond markets which, if not supplemented, would have interfered with monetary policy transmission. Moreover, it was claimed the reason underpinning the ECB's interventions was not true sovereign risk, but the emergence of "severe distortions in financial markets [as well as a higher] level of uncertainty [which meant that] a more non-standard liquidity management by the central bank [was] needed to prevent dysfunctional markets from interfering with the effective transmission of the monetary policy stance [50]".

In the context of market neutrality, however, this claim is surely unsustainable. European sovereign debt markets in 2010 were not "dysfunctional"; they were reacting to the very real possibility that, given their parlous financial conditions, certain periphery Eurozone countries were likely to default on their bond commitments, and a recognition that their national banking systems were severely undercapitalised. The prices of bonds from certain countries were provided with support mechanisms which were not available to the debt securities of other Eurozone member states and a floor was placed under their price by the ECB's willingness to act as a buyer of last resort. Whatever the merits of pursuing this policy for other means-namely the higher order considerations of financial stability and the preservation of the Eurozone-these interventions cannot be described as market neutral. Notwithstanding the debate over whether these programmes were in breach of the EU's prohibition of monetary financing of states [24], it is clear that the ECB in effect became a market maker in government securities. Indeed, this was part of the basis for the German court's declaration in 2020 that the Bundesbank's participation in the PSPP — of which the EFSF and ESM are large constituent parts—-breached constitutional law. ${ }^{14}$

The EFSF is but one example of the abandonment of the market neutrality principle by the ECB in the realm of monetary policy. In relation to the CSPP, for example, the ECB largely confines its purchases to listed assets, in particular corporate bonds. Firms that have issued neither equity nor bonds are generally out of scope of extraordinary monetary policy funding. European credit markets are dominated by bank finance rather than capital market finance, hence the Commission's promotion of the Capital Markets Union project. European corporates, particularly smaller firms, depend

\footnotetext{
14 The court held that "the CJEU allows asset purchases even in cases where the purported monetary policy objective is possibly only invoked to disguise what essentially constitutes an economic and fiscal policy agenda. [55, para. 136]".
} 
upon bank credit for funding. This means that the distributional consequences of QE may be profound: when a central bank indicates that it will purchase assets of a specific type, the demand for those assets will, all things equal, rise, and therefore, the yields on those assets will fall. Put differently, the central bank entering a market for securities will increase the liquidity of those securities, lower the funding costs of the issuing entities and place entities which do not issue bonds, or those entities not included in any purchase programme, at a competitive disadvantage, a consequence recognised by the ECB itself $[1,70]$. Issuing bonds is a complex, technical and costly exercise, and any new entrants to the bond market would be highly unlikely to satisfy the eligibility requirements for admission to the CSPP, especially in relation to credit standards. Market neutrality in monetary policy would also imply that bonds would be purchased from any sector and at any investment rating. Yet, the ECB places restrictions on investment in many forms of bond issued by the financial sector. Further, the ECB refuses to purchase corporate bonds which are not investment-grade level under its CSPP. Until the Covid-19 pandemic, it would also sell any corporate bonds that it held in its portfolio if those bonds suffered a ratings downgrade, although this requirement has now been relaxed.

Given that investment capital for bond financing is limited in volume, it is clear that conditionality of this sort does not meet a market-neutrality test, however defined; such programmes implicitly favour corporations which rely on external bond-financing to a greater degree, as well as those firms with the capacity to issue debt instruments rapidly at low cost. ${ }^{15}$ The approach adopted creates winners and losers in the market for corporate finance: firms which are heavily bond-financed get access to cheap funding whilst those which are funded by equity do not. ECB officials have made it clear recently that they will consider further interventions in monetary operations in order to mitigate climate risk [59, 69].

The market neutrality principle has also been undermined in the field of bank supervision, primarily in capital adequacy regulation. Indeed, legislative provisions explicitly state that capital requirements may be subject to "targeted adjustments in order to reflect EU specificities and broader policy considerations [44]". The primary purpose of capital requirements is to mitigate prudential risks by ensuring there is a large enough capital buffer to absorb losses in the event of an impairment of a financial institution's assets.

\footnotetext{
15 See Thomas Hale [53] ("Alongside a reduction in the outstanding universe of highly-rated assets, the sheer volume of purchases has placed huge downward pressure on bond yields.") and Sid Verma [71] (relaying a market analyst's argument that the ECB's corporate bond purchases have "distorted the relative value of debt issued by a number of European companies").
}

Capital requirements are tailored according to the credit risk of the financial products in question. In the EU, such capital requirements are already set for all EU credit institutions under the Capital Requirements Regulation (CRR2), the regulatory instrument governing the ECB's supervision of banks which became effective in 2014 [46].

In a departure from risk-based regulatory principles established under the Basel Accords, EU policymakers instructed the ECB to amend its prudential framework to support finance for specific forms of venture, namely the granting of loans to small-and-medium enterprises (SMEs). SME loans are now accorded preferential capital treatment under SME Supporting Factor (SME SF) under Article 501 of CRR2. According to the European Banking Authority (EBA), the SME SF "was introduced by the CRR to allow credit institutions to counterbalance the rise in capital requirements resulting from [Basel III Capital Accord] and to provide an adequate flow of credit to this particular group of companies." [30, 49 Under those EU rules, capital requirements for such business loans are almost 25 per cent below what they otherwise would be [30, 49]. Research is limited as to their overall effectiveness, but findings from France indicate that lending to SMEs attributable to the SME SF increased by at least ten percent [28]. Similar preferential treatment for infrastructure projects is found in EU insurance company regulation [22].

In further evidence that regulatory co-operation in this field has the potential for further disruption, senior officials at the EU Commission have requested that the EBA explores the feasibility of lowering capital requirements against certain so-called green assets which have their purpose as climate change mitigation, ${ }^{16}$ principally in order to accelerate the EU's commitment to net zero carbon emissions by the year 2050 [40]. These moves have been resisted somewhat by the ECB unless significant differentiation with regard to the credit risk of "green" assets can be demonstrated. Notwithstanding this, CRR2 includes a novel mandate requiring the EBA to assess whether to introduce dedicated prudential treatment of exposures in the case of assets or activities substantially associated with environmental and/or social objectives [46, Art. 501c]. Changes to the prudential treatment of such assets would have to be supported by evidence that they are economically less risky. Any divergence by the EBA from the ECB in its recommendations on policy solutions may create further tensions between EU supranational

\footnotetext{
16 See Valdis Dombrovskis [29], where he stated that the Commission is "looking positively at the European Parliament's proposal to amend capital charges for banks to boost green investments and loans by introducing a so-called green supporting factor".
} 
institutions. Indeed, in an indication of travel in this area at least one European NCB has already adopted such a policy. ${ }^{17}$

\section{Financial stability}

As noted above, from a financial stability perspective, the chief concern in relation to the introduction of a CBDC is the effect on the banking system that such an innovation may exert. Several highly ranked officials in EU countries have argued that on this basis the introduction of CBDCs might be undesirable $[6,18,62]$. Yet, it is far from clear that introducing a CBDC would necessarily entail disintermediation of the banking system. Such an outcome is inter alia dependent partly on banks' endogenous response to the introduction of a CBDC and also on the design choice of the CBDC system made by the relevant central bank, which is a policy variable.

One cannot predict banks' response, but they have options. Banks earn significant premia via their credit and maturity transformation functions. They are able to adjust deposit rates to attract funding and can recoup such costs by increasing their loan interest rates. This is particularly true in relation to banks with greater market power, as they can insulate their earnings on loans whilst maintaining lending levels. Moreover, even if banks found it more costly to compete in such an environment and were to lose some of the spreads they earn from the funding subsidies they currently enjoy, it is unclear how this outcome would be suboptimal from an efficiency perspective. ${ }^{18}$

There also may be significant macro-economic benefits to the introduction of a CBDC. In a financial world in which institutions rely upon the production of a constant flow of safe assets to act as repositories for capital and for funding purposes, CBDCs provide a new asset class of secure central bank instruments, no different in credit or liquidity terms than bank reserves [52]. Large institutional cash pools held by money managers cannot be deployed in meaningful volumes into bank deposits, thanks to deposit insurance caps which limit the utility of deposits as stores of value. This, in turn, reduces the supply of safe assets to the financial system and has contributed to the growth of shadow banking which, at its core, is a system designed to cater to the institutional need for private forms money. History has demonstrated on numerous occasions that runs on forms of such private money-substitutes present systemic threats to the wider economy [68, pp. 13-14].

\footnotetext{
17 In 2020, the Hungarian central bank introduced a green supporting factor for certain "green" financial products [60].

18 As noted by Ricks et al.: "[A CBDC] might increase banks' funding costs by removing distortive subsidies-but that would be a good thing [68, p. 40]".
}

Because non-banks would have the option of holding CBDC funds at the central bank, and on the assumption that CBDCs pay a rate of interest, a CBDC could increase the responsiveness of an economy to changes in the policy rate. If any entity in the economy can earn the central bank rate, there would be no incentive to place their funds on deposit or make loans for lower than the rate they could earn at a risk-free rate from the central bank. This in turn makes the interest rate tool more efficacious. Moreover, if private forms of money such as stablecoins or alternative currencies capture a sufficiently large proportion of the payment instruments market, the transmission of monetary policy would be severely weakened and restrict the capacity of the central bank to support markets during times of stress.

In relation to CBDC design considerations, there are methods through which banks might be insulated from the impact on funding that the introduction of a CBDC may exert. The most convincing from the perspective of preserving bank funding is arguably the proposal to offer differentiated—or tiered-remuneration to CBDC reserves [14]. Central banks in many jurisdictions (including in relation to certain accounts in the $\mathrm{EU}^{19}$ ) currently apply reserve tiering to the remuneration of central bank reserves, in an attempt to influence the volume of deposits held in reserve accounts. As discussed above, in the EU system central bank reserves are remunerated at the bank's policy interest rate. Under these systems, a relatively attractive premium is applied to reserves up to a quantitative ceiling. Beyond this ceiling, a lower interest rate-sometimes a penalty rate-is applied to larger amounts.

This system has several key advantages over a blanket introduction of CBDCs. First, it would permit central banks to construct a payments system which could be used for retail payments services, whilst disincentivising entities from utilising CBDCs as stores of value for larger depositors. Any interest rate on the primary tier of CBDC should not fall below zero, but the quantitative limits referred to would be relatively low, so that such CBDC accounts could be used as payment channels but no so large as to instigate a widespread flow of deposits from commercial banks into CBDC; as noted by Bindseil and Panetta, "central bank money should not become a large-scale store of value (i.e. a major form of investment), as in that case the central bank would effectively become an intermediary for private savings (a development that would have no particular justification). [15]" If offered universally, such a CBDC would likely prove attractive to households without overly threatening bank intermediation structures. Under such a

\footnotetext{
${ }^{19}$ For example, Article 4 of the Eurosystem's DALM guidelines specifies that a two-tier remuneration system applies to government deposits.
} 
system, central banks would still retain control of monetary policy, as well as the power to impose negative interest rates if required. Alternatively, the CBDC could be provided in token form and held in digital wallets, in the same way that banknotes - which are claims on the central bank-are held in physical wallets today. Commercial banks and other financial institutions could offer such digital wallet services securely to their retail and business clients; it would be unlikely that users would store such tokens in numbers greater than they would need for everyday needs, as such instruments - as with cash-are vulnerable to loss or theft [5, pp. 85-100].

A further option would be to introduce a so-called synthetic CBDC (sCBDC) [2]. In effect, technology firms would be permitted to hold central bank accounts, in a similar way that commercial banks do now. However, rather than these accounts comprising central bank reserves, as is the case with depository institutions, the accounts would contain CBDC. Private tech firms would then issue their own e-money ("stablecoins") which would be tethered to the central bank account. The central bank would merely offer settlement services to e-money providers. sCBDC would therefore differ from first-order CBDCs in that private entities would maintain account relationships with customers, rather than the central bank itself. This proposal would arguably preserve central bank legitimacy to a greater extent than a fully fledged CBDC, whilst allowing the private sector to innovate in the payments system space. It would also be expected to increase payments market efficiency, by carving out a payments infrastructure with access to the central bank's balance sheet which is not routed through incumbent banks. In this way, competitor institutions would have the ability to tap into the central bank framework and diminish the market power of existing large financial institutions.

In combination, these factors might increase efficiency within the payments sector, and also improve financial stability by broadening the landscape of institutions able to offer settlement services in central bank money. It would also arguably reduce the potential for a further financial stability risk from crystallising: the risk that rival unregulated currencies and means of payment might emerge to rival fiat money and undermine EU regulatory capacities. Planned forms of such alternative currencies anchor themselves to fiat money in order to gain broad acceptance and trustworthiness. Facebook's launch of Diem in 2021 (backed one for one by the US dollar) has been announced for 2021. However, in the absence of regulatory oversight, the potential for an alternative currency network to become established and highly trusted-given the leveraging potential of the Facebook data network and its accessibility to households-the link between underlying fiat money and the payment mechanism might weaken over time. As an alternative form of monetary instrument, widespread adoption of Diem might not only pose a threat to the banking system by disintermediating payments further, but also reduce the efficacy of central bank monetary policy. In contrast, with a CBDC, central banks would have the option of paying interest on reserve balances held by alternative payments providers in reserve accounts, thus transmitting policy rates to consumers. By offering a standardised and non-proprietary interoperable payments infrastructure, this might also ensure that large tech firms could not come to dominate payments markets, in effect avoiding the replacement of one set of dominant institutions by another. ${ }^{20}$

\section{Conclusion}

The exploration of CBDC technologies represents a much deeper contemplation of the role of money and banking in an increasingly digitalised world. In relation to any introduction of any new financial technology, an assessment of the balance of risks must be undertaken. This article has sought to demonstrate that any limits to the ECB's capacity to issue a CBDC are not necessarily constitutional. In the event, it may be plausibly argued that market solutions to improving payments efficiency and competition in the payments market might be preferred to central bank intervention. These factors are arguably more significant given the nature and functioning of the ESCB, which is characterised by a dispersal of authority and occasional reconciliation between competing national priorities. Factors such as financial inclusion, access to payments market infrastructure, and incumbent bank competitive power remain problematic across the bloc. Whilst there may be valid justifications for the continued reticence of certain ECB officials to countenance the introduction of a CBDC, those concerning financial stability and market neutrality are not necessarily supported when considered in wider contexts. Indeed, in contrast with many of these claims, the introduction of an EU-wide CBDC would likely intensify competition in the retail payments market, improve financial inclusion levels and could even enhance financial stability.

\footnotetext{
${ }^{20}$ See, for example, the Governor of the Banque de France, arguing that: "The risk [is] that BigTechs, leveraging on their global reach, will build private financial infrastructures and 'monetary' systems, competing with the public monetary sovereignty since they will position themselves as issuers and managers of a universal 'currency' [26]".
} 


\section{Declaration}

Conflict of interest The author states that there is no conflict of interest.

\section{References}

1. Abidi, N. and I. Miquel-Flores. 2018. Who benefits from the corporate QE? A regression discontinuity design approach. ECB Working Paper Series no. 2145, Frankfurt am main.

2. Adrian, T. and T. Mancini-Griffoli. 2019. The rise of digital money. IMF FinTech Note no. 01, Washington, DC.

3. Alogoskoufis, S. and S. Langfield. 2019. Regulating the doom loop. ECB Working Paper Series no 2313, Frankfurt am main.

4. Andrade, $\mathrm{P}$. et al. 2016. The ECB's asset purchase programme: An early assessment. ECB Discussion Paper no. 1956, Frankfurt am main.

5. Auer, R. and Böhme R. 2020. The technology of retail central bank digital currency. BIS Quarterly Review March 2020, Basel.

6. Balz, B. 2020. Digital currencies, global currencies. In Speech at the China Europe Finance Summit-A Hybrid Conference on Sino-European Capital Markets. Virtual event, 20 October.

7. Balz, B. 2020. Forming a competitive European payments market that benefits society at large. The EUROFI Magazine, April 2020, pp. 173-174.

8. Bank for International Settlements. 2003. The Role of Central Bank Money in Payment Systems. Basel: Bank for International Settlements.

9. Bank for International Settlements. 2018. Central Bank Digital Currencies. Committee on Payments and Market Infrastructures Markets Committee Paper no. 174, Basel.

10. Bank for International Settlements. 2020. Central banks and payments in the digital era. BIS Annual Economic Report June 2020, Basel.

11. Bank for International Settlements. 2020. Payment aspects of financial inclusion in the fintech era. Committee on Payments and Market Infrastructures Paper no. 191, Basel.

12. Barrdear, J., and M. Kumhof. 2016. The macroeconomics of central bank issued digital currencies. Bank of England Staff Working Paper no. 605, London.

13. Basel Committee on Banking Supervision. 2020. The Basel Framework. Basel: Bank for International Settlements. https:// www.bis.org/basel_framework/index.htm.

14. Bindseil, U. 2020. Tiered CBDC and the financial system. ECB Working Paper Series no. 2351, Frankfurt am main.

15. Bindseil, U., and F. Panetta. 2020. Central bank digital currency remuneration in a world with low or negative nominal interest rates. VoxEU, 5 October.

16. Bossu, W. et al. 2020. Legal Aspects of Central Bank Digital Currency: Central Bank and Monetary Law Considerations. IMF Working Paper no. 2020/254, Washington, DC.

17. Campbell, A., and P. Moffatt. 2013. Protecting Bank Depositors After Cyprus. Nottingham Insolvency and Business Law eJournal 1 (4): 27-50.

18. Carstens, A. 2019. The future of money and payments. Speech at the Central Bank of Ireland 2019 Whitaker Lecture. Dublin, 22 March.

19. Central Bank of Iceland. 2018. Rafkrona? Central bank digital currency. Special Publication no. 12, Reykjavik.

20. Central Bank of the Bahamas. Sand Dollar-Digital Bahamian Currency, FAQs. http://www.sanddollar.bs/.
21. Cheun, S., I. Von Köppen-Mertes, and B. Weller. 2009. The collateral frameworks of the Eurosystem, the Federal Reserve System and the Bank of England and the financial market turmoil. ECB Occasional Paper no. 107, Frankfurt am main.

22. Commission Delegated Regulation (EU) 2017/1542 of 8 June 2017 amending Delegated Regulation (EU) 2015/35 concerning the calculation of regulatory capital requirements for certain categories of assets held by insurance and reinsurance undertakings (infrastructure corporates). OJ L 236/14, 14 September 2017.

23. Consolidated Version of the Treaty on the Functioning of the European Union. OJ C 326, 26 October 2012.

24. Consolidated Version of the Treaty on the Functioning of the European Union Protocol (No 4) on the Statute of the European System of Central Banks and of the European Central Bank. OJ C 202, 7 June 2016.

25. Croman, K., et al. 2016. On Scaling Decentralized Blockchains In Financial Cryptography and Data Security, ed. J. Clark, et al. Berlin: Springer.

26. De Galhau, V.F. (2020) Preparing Europe Payments for the digital currency age. Speech at Bundesbank conference Banking and Payments in the digital world. Berlin, 11 September.

27. De Nederlandsche Bank. 2020. Central Bank Digital Currency: Objectives, preconditions and design choices. DNB Occasional Study no. 1, Amsterdam.

28. Dietsch, M., H. Fraisse, M. Lé, and S. Lecarpentier. 2019. Lower bank capital requirements as a policy tool to support credit to SMEs: evidence from a policy experiment. EconomiX Working Papers no. 12. Nanterre: University of Paris Nanterre

29. Dombrovskis, V. 2017. Greening finance for sustainable business. In Speech at the One Planet Summit. Paris, 12 December.

30. European Banking Authority. 2016. Report on SMEs and SME Supporting Factor. EBA Opinion no. 04. London, UK

31. European Banking Authority. 2018. Report on the Impact of Fintech on Incumbent Credit Institutions' Business Models. London: European Banking Authority.

32. European Central Bank. 2003. Background Studies for the ECB's Evaluation of its Monetary Policy Strategy. Frankfurt am main: European Central Bank.

33. European Central Bank. 2019. Card payments in Europe-Current Landscape and Future Prospects: A Eurosystem Perspective. Frankfurt am main: European Central Bank.

34. European Central Bank. 2020. ECB Welcomes Initiative to Launch New European Payment Solution. ECB Press Release, 2 July 2020. https://www.ecb.europa.eu/press/pr/date/2020/html/ecb. pr200702 214c52c76b.en.html.

35. European Central Bank. 2020. ESCB/European Banking Supervision Response to the European Commission's Public Consultation on a New Digital Finance Strategy for Europe/FinTech Action Plan. Frankfurt am main: European Central Bank.

36. European Central Bank. 2020. Pandemic emergency purchase programme (PEPP). https://www.ecb.europa.eu/mopo/implement/ pepp/html/index.en.html.

37. European Central Bank. 2020. Report on a Digital Euro. Frankfurt am main: European Central Bank.

38. European Central Bank. 2020. Study on the Payment Attitudes of Consumers in the Euro Area (SPACE). Frankfurt am main: European Central Bank.

39. European Central Bank. 2020. TARGET Annual Report 2019. Frankfurt am main: European Central Bank.

40. European Commission. 2018. Communication from the Commission to the European Parliament, the European Council, the Council, the European Economic and Social Committee, the Committee of the Regions and the European Investment Bank, A Clean Planet for all A European strategic long-term vision for a prosperous, 
modern, competitive and climate neutral economy. COM(2018) 773 final, 28 November 2018.

41. European Commission. 2020. Communication from the Commission to the European Parliament, the Council, the European Economic and Social Committee and the Committee of the Regions on a Digital Finance Strategy for the EU. COM(2020) 591, 24 September 2020.

42. European Commission. 2020. Communication from the Commission to the European Parliament, the Council, the European Economic and Social Committee and the Committee of the Regions on a Retail Payments Strategy for the EU. COM(2020) 592, 24 September 2020.

43. European Parliament and Council Directive (EU) 2015/2366 of 25 November 2015 on payment services in the internal market. OJ L 337, 23 December 2015.

44. European Parliament and Council Directive (EU) 2019/878 of 20 May 2019 amending Directive 2013/36/EU as regards exempted entities, financial holding companies, mixed financial holding companies, remuneration, supervisory measures and powers and capital conservation measures. OJ L 150, 7 June 2019.

45. European Parliament and Council Regulation (EU) 2015/751 of 29 April 2015 on interchange fees for card-based payment transactions. OJ L 123, 19 May 2015.

46. European Parliament and Council Regulation (EU) No 575/2013 of 26 June 2013 on prudential requirements for credit institutions and investment firms and amending Regulation (EU) No 648/2012. OJ L 176, 27 June 2013.

47. Evans, D. 2014. How the Proposed Payments Legislation Will Restrain Competition Among Payment Card Schemes and Harm Consumers in the European Union. Antitrust Chronicle 10(2).

48. Ferreira, C. 2013. Bank market concentration and bank efficiency in the European Union: A panel Granger causality approach. International Economics and Economic Policy 10 (3): 365.

49. Fromage, D. (special issue) [to be formatted].

50. González-Páramo, J.M. 2011. The ECB and the sovereign debt crisis. In Speech at the XXIV Moneda y Crédito Symposium. Madrid, 4 November.

51. Goodhart, C.A.E. 1975. Problems of Monetary Management: The U.K. Experience. Papers in Monetary Economics 1 Reserve Bank of Australia.

52. Habib, M.M., Stracca, L. and Venditti, F. (2020) The fundamentals of safe assets. Frankfurt am main, Germany. ECB Working Paper Series no. 2355.

53. Hale, T. 2017. ECB Bond Buying Transforms Universe of Top Tier Debt. Financial Times, 28 November.

54. Ingves, S. 2020. Future Money and Payments. Economic Commentaries no. 9. Stockholm: Sveriges Riksbank.

55. Judgment of the Second Senate of 05 May 2020. 2020. 2 BvR 859/15 (BVerfG).

56. Lagarde, C. 2020. Payments in a digital world. In Speech at the Deutsche Bundesbank Online Conference on Banking and Payments in the Digital World. Frankfurt am main, 10 September.

57. Lane, P.R. 2012. The European Sovereign Debt Crisis. Journal of Economic Perspectives 26 (3): 49.

58. Libra Association Members. 2020. White Paper. White Paper no. v2.0. Geneva: Libra Association.
59. Look, C. 2020. Lagarde Says ECB Needs to Question Market Neutrality on Climate. Bloomberg.

60. Magyar Nemzeti Bank. 2019. MNB introduces a Green Preferential Capital Requirement Programme. 18 December 2019, https:// www.mnb.hu/en/pressroom/press-releases/press-releases-2019/ mnb-introduces-a-green-preferential-capital-requirement-progr amme.

61. McLeay, M., A. Radia, and R. Thomas. 2014. Money Creation in the Modern Economy. London: Bank of England Quarterly Bulletin Q1.

62. Mersch, Y. 2020. An ECB digital currency-A flight of fancy? In Speech at the Consensus 2020 Conference. Virtual event, 11 May.

63. Murphy, H. 2020. Facebook's Libra currency to launch next year in limited format. Financial Times, 27 November.

64. Nabilou, H. 2019. Testing the waters of the Rubicon: The European Central Bank and central bank digital currencies. Journal of Banking Regulation 21 (4): 299.

65. Norges Bank. 2020. Status report-Norges Bank's central bank digital currency project. Norges Bank Papers no. 2, Oslo, Norway.

66. Pistor, K. 2019. Facebook's Libra must be stopped. Social Europe, 24 June 2019.

67. Ricks, M. 2016. The Money Problem: Rethinking Financial Regulation. University of Chicago Press.

68. Ricks, M., J. Crawford, and L. Menand. 2020. FedAccounts: Digital Dollars. Vanderbilt Law Research Paper 18-33, UC Hastings Research Paper no. 287, George Washington Law Review (forthcoming).

69. Schnabel, I. 2020. When markets fail-The need for collective action in tackling climate change. In Speech at the European Sustainable Finance Summit. Frankfurt am main, 28 September.

70. Van 't Klooster, J., and C. Fontan. 2020. The Myth of Market Neutrality: A Comparative Study of the European Central Bank's and the Swiss National Bank's Corporate Security Purchases. New Political Economy 25 (6): 865.

71. Verma, S. 2017. These Anomalous Spreads Show ECB Distorting Bond Markets. Bloomberg.

72. Weidmann, J. 2019. Climate change and central banks. In Speech at the Deutsche Bundesbank's Second Financial Markets Conference. Frankfurt am main, 29 October.

73. Williams, M.T. 2014. Testimony of Mark T. Williams to U.S. House of Representatives Committee on Small Business. Testimony presented at Hearing Bitcoin: Examining the Benefits and Risks for Small Business. Washington DC, 2 April.

74. World Savings Banks Institute. 2016 Close to 40 million EU citizens outside banking mainstream. WSBI Latest News, 5 April.

Publisher's Note Springer Nature remains neutral with regard to jurisdictional claims in published maps and institutional affiliations.

Jay Cullen is Professor of Financial Regulation at the University of York and Adjunct Research Professor at the University of Oslo. 